\title{
Kinderseksualiteit: Noodsaaklike riglyne vir elke ouer
}

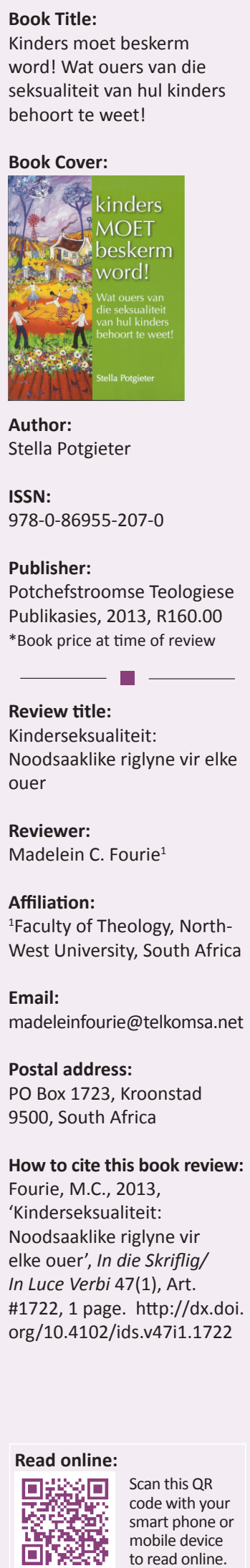

Seksuele molestering is 'n saak van erns met ingrypende en vernietigende gevolge vir diegene wat gemolesteer word, gesinne van die gemolesteerde en ten laaste ook vir die breë samelewing. 'n Praktiese en informatiewe gids rakende die tersake aangeleentheid is daarom nie net ' $n$ wins nie, maar ook 'n noodsaaklikheid.

Hierdie boek is 'n eerste publikasie uit die pen van Stella Potgieter. Dit is die hart van die skrywer om ouers so goed moontlik toe te rus met die nodige kennis, insig en begrip rakende die ontwikkeling van kinders se seksualiteit. Potgieter is nóú betrokke by die terapeutiese proses van mans, vroue en kinders wat hulle aan kindermolestering skuldig maak. Sy beskik oor deeglike kennis en 'n wye ervaringsveld van die betrokke onderwerp. Haar hoofdoel is juis om oortreders op so 'n wyse te begelei dat seksuele wandade deur die betrokke persone gestaak word en kinders sodoende beskerm word. Die voorgestelde voorkomingsmaatreëls is dus daarop gerig om ouers te bemagtig ten einde kinders teen seksuele molestering te beskerm.

Die inhoud van die boek word in twee afdelings verdeel. Afdeling een plaas seksualiteit in 'n bybelse verwysingsraamwerk met die fokus op seksualiteit as ' $n$ wonderlike gawe van God. Ter agtergrond word 'n kort oorsig aangaande ouderdomsgepaste seksuele gedrag van kinders en adolessente gebied. Die noodsaaklikheid van ouer-kindgespreksvoering rakende seksualiteit en seksuele molestering word deur die skrywer baie sterk onderstreep en bepleit. Praktiese voorbeelde dra by tot die vergemakliking van die wyse (hoe?) waarop die onderwerp gehanteer kan word met die meegaande inhoudelike (wat?) van sodanige gesprek. Die presiese neerpen van wat seksuele molestering behels en die identifikasie van gevaartekens teenwoordig by slagoffers, rus die leser met die nodige begrip toe. Ter voorkoming aan die blootstelling van moontlike seksuele wandade, word 'n veiligheidsplan vir gesinne met gesinsreëls en -grense as fokus voorgestel.

Afdeling twee hanteer die moeilike kwessie rakende seksueel-afwykende gedrag en pedofilie as fenomeen geniet ook aandag. Die siening dat pedofilie ' $n$ vorm van seksueel-afwykende gedrag is, word gehandhaaf en die skrywer doen moeite om juis hierdie aanname te motiveer. Gepaardgaande boublokke tot 'n seksuele verslawing en die afwykende gedragsiklus van 'n pedofiel verleen insig aan die leser vir toekomstige voorkomendende optrede. 'n Verdere aanname wat gemaak word, is dat ' $n$ persoon wat kinders molesteer nie met die molestering sal voortgaan indien die persoon besef dat die publiek oor die wandade van die spesifieke persoon ingelig is nie. Behandelingsprosedures en gevallestudies met positiewe uitkomste ter ondersteuning van hierdie aanname bring hoop vir oortreders, slagoffers van seksuele wandade en die gemeenskap waarbinne die oortreder funksioneer.

Die boek is in 'n populêr-wetenskaplike styl geskryf en die waarde van hierdie publikasie is ongetwyfeld ingebed in die praktiese aard daarvan. Die boodskap is duidelik: voorkoming is beter as nasorg! Vandaar die gepaste en vermanende titel: Kinders MOET beskerm word!

Hierdie boek word ten slotte vir elke ouer aanbeveel. Ouers voel dikwels ontoereikend in die taak van seksuele opvoeding. Die boek hanteer juis hierdie onvermoë op 'n maklik verstaanbare wyse. Dit is 'n 'móét-lees'- en ook 'n 'móét-doen'-gids om pynlike, emosionele lewenservarings vir kinders te bekamp. Diegene wat wel aan seksuele molestering blootgestel word, sowel as die oortreder self kan die nuutverworwe insig tot hulpverkryging aanwend vir 'n nuwe, hoopvolle toekoms. Alle beroepe waar kinders die primêre fokus is, insluitende hulpverlenende beroepe waar gespesialiseerde aandag rakende seksuele molestering en seksuele afwykende gedrag vereis word, sal by hierdie insiggewende, praktiese en waardevolle gids baat vind! 